\title{
PENGEMBANGAN PERANGKAT PEMBELAJARAN IPA TERPADU TIPE WEBBED BERBASIS INKUIRI TERBIMBING UNTUK MELATIH KEMANDIRIAN BELAJAR DAN KECAKAPAN HIDUP SISWA SMP
}

\author{
Syamsudin'), Muslimin Ibrahim²), Wahono Widodo ${ }^{3)}$ \\ ${ }^{1)}$ Mahasiswa Program Studi Pendidikan Sains, Program Pascasarjana Universitas Negeri Surabaya \\ ${ }^{2), 3)}$ Dosen Pascasarjana Prodi Pendidikan Sains Universitas Negeri Surabaya \\ E-mail: syamsudin.alghifari@yahoo.com
}

\begin{abstract}
Abstrak: Telah dilakukan penelitian pengembangan perangkat pembelajaran IPA terpadu tipe webbed (Silabus, RPP, LKS, Buku Siswa, Tes Hasil Belajar) dengan model inkuiri terbimbing yang bertujuan untuk melatih kemandirian belajar dan kecakapan hidup siswa SMP. Perangkat pembelajaran dikembangkan menggunakan model 4D (four D model) terdiri dari tahap pendefinisian (define), perancangan (design), pengembangan (develop) dan penyebaran (disseminate). Perangkat pembelajaran divalidasi oleh para pakar untuk mengetahui validitas perangkat dan diujicoba pada 35 siswa kelas VII SMP semester gasal tahun ajaran 2015/2016 dengan rancangan One-Group Pre test and Post test Design. Analisis data dilakukan secara deskriptif kuantitatif-kualitatif dengan hasil: 1) Validitas perangkat kategori sangat valid (skor 3.63); 2) Keterbacaan LKS menunjukkan $100 \%$ isi LKS menarik dan mudah dipahami, $82.86 \%$ penampilan LKS menarik dan keterbacaan Buku Siswa terbaca dan layak digunakan untuk siswa SMP dengan rata-rata jumlah kalimat sampel bacaan yang diambil peneliti adalah 5,93 kalimat dalam 100 kata dengan rata-rata jumlah suku kata 145,$2 ; 3)$ Keterlaksanaan sangat baik (skor rata-rata 3.71); 4) siswa merespon sangat positif (97.14\%); 5) Aktivitas siswa bersifat student center; 6) Hasil belajar siswa meningkat (N-gain 0.74); 7) Kemandirian belajar dan kecakapan hidup siswa meningkat. Simpulan penelitian ini adalah perangkat pembelajaran IPA terpadu tipe webbed berbasis inkuiri terbimbing yang dikembangkan sudah valid, praktis, dan efektif untuk melatihkan kemandirian belajar dan kemampuan kecakapan hidup siswa SMP.
\end{abstract}

Kata kunci: Model Inkuiri Terbimbing, IPA Terpadu Tipe Webbed, Kemandirian Belajar, Kecakapan Hidup Siswa.

\begin{abstract}
Research has been done to develop the kind of integrated science teaching type webbed (Syllabus, Lesson Plans, Student Work Sheet, Student Book, Student Achievement Test) with guided inquiry model that aims to teach self directed learning and life skills junior high school students. Learning materials developed by four D model there are define, design, develop, and disseminate. Learning materials were validated by the experts to determine the validity of the materials and tested on 35 students of grade VII junior high school odd semester academic year 2015/2016 using the One Group Pre-test and Post Test Design. The data were analyzed by descriptive quantitative-qualitative. The results are: 1) The validity of the materials is very valid category (score 3.63 ); 2) Readability worksheet shows $100 \%$ the content interesting and easy to understand, $82.86 \%$ Student Work Sheet attractive appearance and legibility Student Book legible and suitable for use in junior high school students with an average number of sample sentences readings taken by researchers is 5.93 sentence in 100 words with the average number of syllables $145.2 ; 3$ ) the successful is very good (average score of 3.71 ); 4) The students responded very positively (97.14\%); 5) Student's activities are student centered type; 6) increased student learning achievement (N-gain 0.74); 7) The self directed learning and improve students' life skills. The conclusions of this research are integrated science teaching materials types based guided inquiry type webbed developed is feasible to use in teaching self directed learning and ability of life skills junior high school students.
\end{abstract}

Keywords: Guided Inquiry Model, Integrated Science Type Webbed, Self Directed Learning, Student Life Skills.

\section{PENDAHULUAN}

Perkembangan ilmu pengetahuan dan teknologi saat ini dirasakan semakin pesat. Untuk menyesuaikan perkembangan ilmu pengetahuan dan teknologi, maka peningkatan kualitas pendidikan merupakan upaya yang harus dilakukan. Salah satu upaya pemerintah untuk meningkatkan mutu pendidikan baik untuk sekolah dasar, sekolah menengah, maupun perguruan tinggi adalah senantiasa berusaha menyempurnakan kurikulum. Salah satu contoh penyempurnaan kurikulum adalah diberlakukannya kurikulum 2013.

Strategi pembelajaran harus diarahkan untuk memfasilitasi pencapaian kompetensi yang telah dirancang dalam dokumen kurikulum agar setiap individu mampu menjadi pebelajar mandiri sepanjang hayat yang pada gilirannya mereka menjadi komponen 
penting untuk mewujudkan masyarakat belajar. Kualitas lain yang dikembangkan kurikulum dan harus terealisasikan dalam proses pembelajaran antara lain kreativitas, kemandirian, kerja sama, solidaritas, kepemimpinan, empati, toleransi dan kecakapan hidup peserta didik guna membentuk watak serta meningkatkan peradaban dan martabat bangsa (Kemendikbud, 2013).

Proses pembelajaran IPA menekankan pada pemberian pengalaman langsung untuk mengembangkan kompetensi agar siswa mampu menjelajahi dan memahami alam sekitar secara ilmiah. Pembelajaran IPA diarahkan untuk mencari tahu dan berbuat sehingga dapat membantu siswa memperoleh pemahaman yang lebih mendalam tentang alam sekitar. Salah satu model pembelajaran yang menekankan untuk secara aktif mencari, mengolah, mengkonstruksi, dan menggunakan pengetahuan adalah model pembelajaran inkuiri.

Life skills adalah sejumlah kecakapan yang dimiliki oleh siswa meliputi persentase kecakapan berpikir (thinking skills), kecakapan sosial (social skills), dan kecakapan akademik/ berpikir ilmiah (academic skills). Kecakapan berpikir (thinking skills) terdiri atas menggali informasi, mengolah informasi, dan pengambilan keputusan; kecakapan sosial (social skills) yakni keterampilan berkomunikasi yang terdiri atas mengajukan pertanyaan, menjawab pertanyaan, mengemukakan pendapat, menanggapi pendapat, dan presentasi lisan; serta kecakapan berpikir ilmiah (academis skills) yang terdiri atas merumuskan masalah, merumuskan hipotesis, menentukan variabel, membuat rancangan percobaan, menyajikan hasil pengamatan dalam bentuk tabel, menganalisis data, dan membuat kesimpulan.

\section{METODE PENELITIAN}

\section{A. Jenis Penelitian}

Jenis penelitian ini merupakan penelitian dan pengembangan (Research and Development). Fokus penelitian pengembangan untuk menghasilkan produk tertentu dan menguji kelayakan, kepraktisan, dan keefektifan produk tersebut. Produk yang dihasilkan dalam penelitian ini berupa perangkat pembelajaran IPA terpadu tipe webbed berbasis inkuiri terbimbing yang meliputi Silabus, RPP, Materi Ajar, LKS, dan Instrumen Penilaian untuk melatihkan kemandirian belajar dan kecakapan hidup siswa SMP.

\section{B. Rancangan Pengembangan Perangkat \\ Pembelajaran}

Pengembangan perangkat pembelajaran pada penelitian ini mengadaptasi pengembangan perangkat model 4D (four D model). Pengembangan perangkat pembelajaran model $4 \mathrm{D}$ terdiri dari tahap pendefinisian (define), perancangan (design), pengembangan (develop) dan penyebaran (disseminate) (Thiagarajan \& Semmel, Semmel, 1974).

\section{Rancangan Implementasi Perangkat Pembelajaran}

Implementasi perangkat pembelajaran ini menggunakan one group pretest-posttest design, dengan menggunakan satu kelompok subyek (Tuckman, 1978; Arikunto, 2010). Langkah pertama melakukan pengukuran sebagai uji awal, selanjutnya dikenakan perlakuan dalam jangka waktu tertentu (3 kali pertemuan), kemudian dilakukan uji akhir. Gambaran implementasi perangkat pembelajaran penelitian ini adalah sebagai berikut:

\section{$\mathrm{O}_{1} \times \mathrm{O}_{2}$}

Keterangan:

$O_{1}$ adalah pretest atau uji awal yang dilakukan untuk mendeskripsikan hasil belajar produk, kemandirian belajar dan kecakapan hidup siswa.

$X$ adalah perlakuan dengan menerapkan perangkat pembelajaran model guided inquiry.

$\mathrm{O}_{2}$ adalah posttest atau uji akhir yang dilakukan untuk mendeskripsikan hasil belajar produk, kemandirian belajar dan kecakapan hidup siswa setelah diterapkan perangkat pembelajaran model guided inquiry.

\section{Teknik Pengumpulan Data}

Proses pengumpulan data dalam penelitian ini menggunakan beberapa teknik sebagai berikut:

1. Validasi perangkat pembelajaran

2. Pengumpulan data pada implementasi perangkat pembelajaran yang dikembangkan dengan teknikteknik sebagai berikut:
a. Observasi
b. Angket
c. Diagram/ Grafik Fry
d. Tes

\section{E. Instrumen Penelitian}

Instrumen penelitian adalah alat untuk mengumpulkan data, instrumen-instrumen yang digunakan adalah sebagai berikut:

1. Lembar Validasi Perangkat

Lembar validasi perangkat pembelajaran digunakan untuk acuan penilaian kelayakan komponen perangkat pembelajaran yang dikembangkan. Validasi dilakukan oleh para pakar yang kemudian memberikan skor dan dirata-rata. Lembar validasi yang digunakan untuk mengukur kelayakan perangkat pembelajaran meliputi: a. Lembar validasi Rencana Pelaksanaan Pembelajaran (RPP), b. Lembar validasi Lembar Kerja Siswa (LKS), c. Lembar validasi materi ajar, dan d. Lembar validasi tes hasil belajar. 


\section{Lembar Penilaian Keterbacaan LKS}

Lembar penilaian keterbacaan LKS digunakan untuk mengetahui tingkat keterbacaan LKS. Instrumen yang digunakan berupa lembar angket dengan 6 pertanyaan yang diisi oleh siswa untuk memberi koreksi mengenai keterbacaan LKS.

\section{Diagram Fry}

Diagram/ Grafik Fry digunakan untuk mengumpulkan data keterbacaan siswa terhadap Buku Siswa yang digunakan. Harjasujana dan Mulyati (1997) menyatakan bahwa Formula keterbacaan diagram Fry mendasarkan formula keterbacaannya pada dua faktor yaitu panjang-pendeknya kata dan tingkat kesulitan kata yang ditandai dengan jumlah (banyak sedikitnya) suku kata yang membentuk setiap kata dalam wacana tersebut. Adapun bentuk dari diagram Fry disajikan pada gambar 1 berikut.

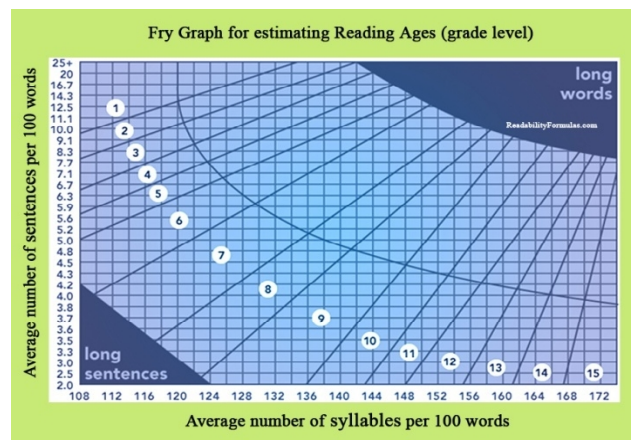

Gambar 1. Diagram Fry untuk mengukur keterbacaan siswa berdasarkan kelas

(Harjasujana dan Mulyati,1997)

4. Lembar Pengamatan Keterlaksanaan Pembelajaran

Lembar pengamatan keterlaksanaan pembelajaran digunakan untuk mengamati keterlaksanaan penerapan pembelajaran IPA dengan pendekatan scientific yang dibuat oleh guru dalam RPP. Instrumen yang digunakan berupa lembar ceklis yang terdiri dari kolom "ya" dan "tidak". Pengamat memberi tanda ceklis pada kolom "ya" apabila tahapan pembelajaran dilakukan oleh guru dan "tidak" apabila tahapan pembelajaran tidak dilakukan oleh guru. Selain itu, pengamat harus memberikan penilaian dengan rentang 1-4.

5. Lembar Pengamatan Aktivitas siswa

Lembar pengamatan aktivitas siswa digunakan untuk mengetahui kegiatan siswa selama kegiatan belajar mengajar dengan menggunakan perangkat pembelajaran. Aktivitas siswa diamati dan dicatat oleh dua orang pengamat pada lembar pengamatan aktivitas siswa setiap lima menit sekali.

\section{Lembar Angket Respon siswa}

Lembar angket respon siswa digunakan untuk mengetahui tanggapan siswa terhadap perangkat pembelajaran yang dikembangkan. Angket ini diisi secara individu dengan memberikan checklist pada kolom options. Angket yang telah diisi dihitung berdasarkan kriteria.

7. Lembar Penilaian Tes Hasil Belajar Siswa

Merupakan istrumen untuk mengukur kemampuan kognitif dan life skills siswa, meliputi kisi-kisi soal tes hasil belajar pengetahuan dan kisi-kisi tes kemampuan life skills. Bentuk instrument kompetensi pengetahuan adalah berupa lembar soal yang berisi 20 butir soal pilihan ganda dengan 4 pilihan jawaban. Penilaian keterampilan life skills berupa lembar tes yang terdiri dari 10 soal uraian mencakup penilaian untuk membuat rumusan masalah, membuat hipotesis, menentukan variabel, membuat rancangan percobaan, menyajikan hasil pengamatan dalam bentuk tabel, membuat analisis data, dan membuat kesimpulan.

8. Lembar pengamatan kemandirian belajar

Lembar kemandirian belajar digunakan untuk mengamati kompetensi-kompetensi yanag akan dilatihkan untuk mencapai kemandirian belajar dalam penelitian ini adalah percaya diri, mampu mengendalikan diri dan bertanggung jawab. Kemandirian belajar siswa selama kegiatan pembelajaran diamati dan diisi oleh dua pengamat yang berasal dari guru atau teman sejawat. Pengamat berada dalam kelas tetapi tidak ikut terlibat dalam kegiatan belajar mengajar sehingga proses pengamatan kemandirian belajar siswa tidak mengganggu proses pembelajaran.

9. Lembar pengamatan kemampuan Life Skills

Lembar pengamatan life skills digunakan untuk mengamati kecakapan bertanya, menjawab pertanyaan, mengeluarkan pendapat, menanggapi pendapat dan presentasi lisan. Life skills siswa selama kegiatan pembelajaran diamati dan diisi oleh dua pengamat yang berasal dari guru atau teman sejawat. Pengamat berada dalam kelas tetapi tidak ikut terlibat dalam kegiatan belajar mengajar sehingga proses life skills siswa tidak mengganggu proses pembelajaran.

\section{HASIL PENELITIAN DAN DISKUSI}

Pengembangan perangkat pembelajaran IPA terpadu tipe webbed berbasis inkuiri terbimbing untuk melatih kemandirian belajar dan kecakapan hidup siswa SMP bertujuan untuk mengamati perkembangan kemandirian belajar dan kecakapan hidup siswa. Berikut ini merupakan deskripsi hasil penelitian yang telah dilakukan.

A. Hasil Pengembangan Perangkat Pembelajaran

1. Analisis Hasil Validasi Perangkat Pembelajaran

a. Silabus

Hasil pengembangan perangkat pembelajaran berupa Silabus IPA terpadu tersebut kemudian divalidasi oleh validator ahli dengan hasil rata-rata validasi Silabus adalah 3,83 dengan kategori sangat valid (Ratumanan \& Laurens, 2006). 
b. Rencana Pelaksanaan Pembelajaran (RPP)

Hasil pengembangan perangkat pembelajaran berupa Rencana Pelaksanaan Pembelajaran (RPP) divalidasi oleh validator ahli dengan hasil rata-rata validasi RPP adalah 3,57 dengan kategori sangat valid (Ratumanan \& Laurens, 2006). Hasil tersebut menunjukkan RPP yang dikembangkan dapat digunakan oleh guru dalam pembelajaran setelah direvisi sesuai saran dari validator.

c. Lembar Kerja Siswa (LKS)

Hasil penilaian validator ahli terhadap lembar kegiatan siswa dengan hasil rata-rata validasi adalah 3.55 dengan kategori sangat valid (Ratumanan \& Laurens, 2006). Hasil tersebut menunjukkan LKS yang dikembangkan valid untuk digunakan oleh guru dalam pembelajaran setelah direvisi sesuai saran dari validator.

\section{d. Buku Siswa}

Buku Siswa yang telah dikembangkan oleh peneliti tersebut kemudian divalidasi dengan hasil rata-rata validasi adalah 3.66 dengan kategori sangat valid (Ratumanan \& Laurens, 2006). Hasil tersebut menunjukkan buku siswa yang dikembangkan valid untuk dijadikan buku panduan bagi siswa maupun guru dalam proses pembelajaran setelah direvisi sesuai saran dari validator.

\section{e. Instrumen Penilaian Hasil Belajar}

Hasil penilaian terhadap pengembangan perangkat tes pengetahuan oleh para ahli menunjukkan bahwa dari aspek isi tes pengetahuan untuk pre test mendapatkan skor rata-rata 3.50 dan soal tes dinyatakan valid, dari aspek bahasa dan penulisan soal mendapatkan skor 3.48 dan dinyatakan valid (Ratumanan \& Laurens, 2006). Sedangkan untuk post test mendapatkan skor 3.83 dan soal tes dinyatakan sangat valid, dari aspek bahasa dan penulisan soal mendapatkan skor 3.48 dan dinyatakan valid (Ratumanan \& Laurens, 2006). Berdasarkan hasil validasi tersebut menunjukkan soal dapat digunakan untuk mengukur tingkat pengetahuan siswa.

Hasil penilaian terhadap pengembangan perangkat tes kemampuan life skills oleh para ahli secara rata-rata menunjukkan bahwa dari aspek isi perangkat ini mendapatkan skor 3.90 dan soal tes dinyatakan sangat valid, dari aspek bahasa dan penulisan soal mendapatkan skor 3.50 dan dinyatakan valid (Ratumanan \& Laurens, 2006). Berdasarkan hasil validasi tersebut menunjukkan soal dapat digunakan untuk mengukur kemampuan life Skills siswa.

\section{Analisis Keterbacaan Perangkat Pembelajaran}

a. Keterbacaan LKS

Berdasarkan hasil analisis keterbacaan LKS menunjukkan bahwa $100 \%$ isi LKS menarik dan gambar/ ilustrasi dari LKS mudah dipahami, 82.86\% siswa menyatakan penampilan dari LKS menarik, sedangkan $28.57 \%$ siswa menyatakan ada kesulitan dari penjelasan LKS dan $20 \%$ siswa menyatakan tidak mengerti dengan pertanyaan yang terdapat di LKS. Hal ini menunjukkan LKS dapat terbaca dan dapat digunakan untuk siswa tingkat SMP.

b. Keterbacaan Buku Siswa

Keterbacaan Buku Siswa dianalisis menggunakan Diagram Fry dengan menggunakan beberapa sampel bacaan pada Buku Siswa.

Hasil sampel tiga bagian bacaan tersebut dirata-rata jumlah kalimat dan suku kata dalam setiap 100 kata disajikan dalam Tabel 3.1 berikut:

Tabel 2. Hasil analisis sampel bacaan Buku Siswa

\begin{tabular}{|l|l|l|l|}
\hline No. & $\begin{array}{l}\text { Sampel Bacaan (100 } \\
\text { kata) }\end{array}$ & $\begin{array}{l}\text { Jumlah } \\
\text { Kalimat }\end{array}$ & $\begin{array}{l}\text { Jumlah } \\
\text { Suku Kata }\end{array}$ \\
\hline 1. & $\begin{array}{l}\text { Bagian satu (Buku } \\
\text { Siswa Halaman 1) }\end{array}$ & 5,86 & 147,6 \\
\hline 2. & $\begin{array}{l}\text { Bagian dua (Buku } \\
\text { Siswa Halaman 5) }\end{array}$ & 6 & 141 \\
\hline 3. & $\begin{array}{l}\text { Bagian tiga (Buku } \\
\text { Siswa Halaman 10) }\end{array}$ & 5,95 & 147 \\
\hline Jumlah & 17,81 & 435,6 \\
\hline \multicolumn{2}{|l|}{ Rata-rata } & 5,93 & 145,2 \\
\hline
\end{tabular}

Berdasarkan Tabel 2 kemudian dicocokkan dengan Diagram Fry seperti pada gambar 3.1 berikut:

Titik temu jumlah kalimat dan suku

kata dalam 100 kata

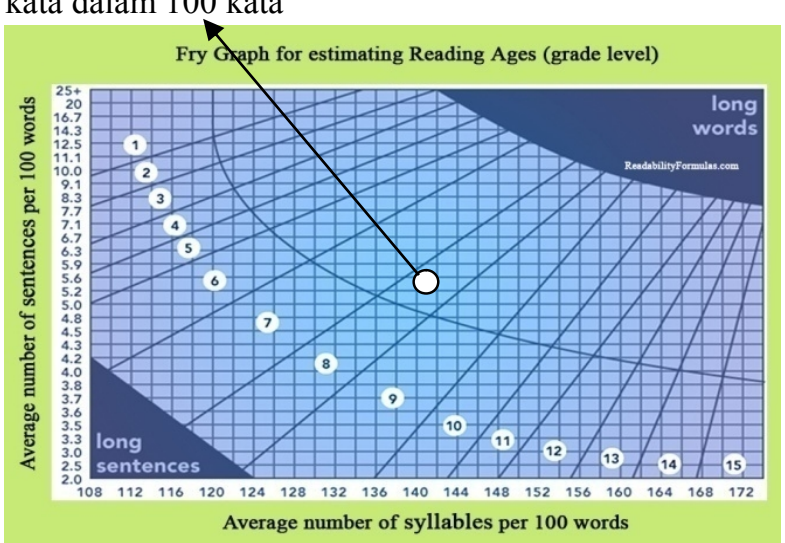

Gambar 2. Analisis Diagram Fry

Berdasarkan analisis menggunakan diagram Fry tersebut menunjukkan bahwa Buku Siswa yang dikembangkan terbaca dan dapat digunakan sebagai panduan belajar untuk siswa kelas VIII dan VIII +1 atau VIII-1 yaitu kelas VII dan IX. Sehingga dapat disimpulkan bahwa Buku Siswa tersebut dapat digunakan oleh siswa pada jenjang SMP.

\section{B. Hasil Uji Coba Perangkat Pembelajaran}

Uji coba dalam penelitian ini merupakan penerapan dari perangkat pembelajaran yang telah dikembangkan dan divalidasi oleh ahli. Uji coba dilakukan di MTs Al Fithrah Surabaya pada semester genap 2015-2016. Ujicoba dilakukan dalam tiga kali pertemuan yang 
sebelumnya dilakukan pre test dan setelah pembelajaran dilakukan post test.

1. Keterlaksanaan Pembelajaran

Keterlaksanaan penggunaan perangkat pembelajaran diamati oleh dua oang pengamat. Pengamatan dilakukan selama 3 kali pertemuan yang merupakan implementasi dari RPP 1, RPP 2, dan RPP 3. Berdasarkan hasil analisis keterlaksanaan penggunaan perangkat pembelajaran yang diamati oleh dua orang pengamat, pengamatan dilakukan selama 3 kali pertemuan yang merupakan implementasi dari RPP 1, RPP 2, dan RPP 3. Berdasarkan beberapa sintaks pembelajaran yang telah ditulis beberapa pakar, maka sintaks pembelajaran inkuiri terbimbing yang dikembangkan berdasarkan Branch \& Oberg (2004).

Pada RPP terdapat tiga kegiatan yaitu pendahuluan, kegiatan inti, dan kegiatan punutup. Hasil penilaian pengamat pada pembelajaran menggunakan perangkat pembelajaran IPA terpadu berbasis inkuiri terbimbing pada pertemuan 1 dengan skor rata-rata 3.42 dengan kategori baik (Ratumanan \& Laurens, 2011) dengan rentang penilaian yang diberikan pengamat antara 2-4. Aspek yang mendapatkan skor terendah (skor 2) oleh kedua pengamat adalah pengelolaan waktu, hal ini dikarenakan pembelajaran pada pertemuan 1 tidak selesai tepat waktu (terdapat penambahan waktu beberapa menit) yang disebabkan siswa terlalu asyik dengan pengamatan dan percobaan sehingga tidak memperhatikan batasan waktu yang telah diberikan. Hasil penilaian dua pengamat pada pertemuan 2 dengan skor rata-rata 3.75 dengan kategori sangat baik (Ratumanan \& Laurens, 2011) dan pertemuan 3 dengan skor rata-rata 3.91 dengan kategori sangat baik (Ratumanan \& Laurens, 2011). Rata-rata penilaian keterlaksanaan pembelajaran menggunakan perangkat pembelajaran IPA terpadu berbasis inkuiri terbimbing pada semua pertemuan adalah 3.69 dengan kategori sangat baik (Ratumanan \& Laurens, 2011). Instrumen keterlaksanaan RPP mempunyai rata-rata reliabilitas 99.24\% dan berkategori baik (Borich, 1994).

\section{Aktivitas siswa}

Pengamatan terhadap aktivitas siswa dilakukan dengan menggunakan lembar pengamatan aktivitas siswa. Pengamatan terhadap aktivitas siswa dilakukan oleh 2 pengamat selama pembelajaran berlangsung yang meliputi: a. mendengarkan dan memperhatikan penjelasan guru, b. membaca LKS dan buku siswa, c. mengajukan pertanyaan atau pendapat, d. melakukan percobaan/ pengamatan, e. mengerjakan LKS/menyelesaiakan tugas belajar, f. mempresentasikan hasil percobaan/pengamatan, $\mathrm{g}$. mendengarkan dan menyimak presentasi, dan $h$. memperlihatkan perilaku tidak relevan dengan pembelajaran. Adapun hasil pengamatan aktivitas siswa dapat dilihat pada Tabel 4.16.
Berdasarkan data pada Tabel 4.16 dan diagram 4.9 didapatkkan persentase tertinggi pertemuan 1, 2 dan 3 yakni aktivitas melakukan pengamatan/ percobaan $26.67 \%$ dan mengerjakan LKS/menyelesaiakan tugas belajar sebesar $16 \%$ dari total keseluruhan aktivitas. Sedangkan persentase terendah pertemuan 1, 2, dan 3 yakni pada aktivitas memperlihatkan perilaku yang tidak relevan saat pembelajaran. Hal ini menunjukkan bahwa siswa dalam kegiatan pembelajaran berada di lingkungan sosial, mereka terus menerus belajar melalui interaksi dengan orang lain di sekitar mereka. Vigotsky berpendapat bahwa perkembangan proses hidup bergantung pada interaksi sosial dan pembelajaran sosial berperan penting untuk perkembangan kognitif (Khulthau \& Todd, 2008).

Tabel 3. Persentase aktivitas siswa

\begin{tabular}{|c|c|c|c|c|c|}
\hline \multirow{2}{*}{$\begin{array}{l}\text { No } \\
\text {. }\end{array}$} & \multirow{2}{*}{$\begin{array}{ll}\text { Aspek } & \text { yang } \\
\text { diamati } & \\
\end{array}$} & \multicolumn{3}{|c|}{ Frekuensi (\%) } & \multirow{2}{*}{$\begin{array}{l}\text { Rata } \\
\text {-rata } \\
\end{array}$} \\
\hline & & P1 & P2 & P3 & \\
\hline 1. & $\begin{array}{l}\text { Mendengarkan } \\
\text { dan } \\
\text { memperhatikan } \\
\text { penjelasan guru }\end{array}$ & 10 & 10 & 10 & 10 \\
\hline 2. & $\begin{array}{l}\text { Membaca LKS } \\
\text { dan buku siswa }\end{array}$ & $\begin{array}{l}14 . \\
4\end{array}$ & 10 & $\begin{array}{l}10 . \\
57\end{array}$ & $\begin{array}{l}11.6 \\
7\end{array}$ \\
\hline 3. & $\begin{array}{l}\text { Mengajukan } \\
\text { pertanyaan atau } \\
\text { pendapat }\end{array}$ & 14 & $\begin{array}{l}15.5 \\
7\end{array}$ & $\begin{array}{l}13 . \\
14\end{array}$ & $\begin{array}{l}14.2 \\
4\end{array}$ \\
\hline 4. & $\begin{array}{l}\text { Melakukan } \\
\text { percobaan/ } \\
\text { pengamatan }\end{array}$ & 25 & 25 & 30 & $\begin{array}{l}26.6 \\
7\end{array}$ \\
\hline 5. & $\begin{array}{l}\text { Mengerjakan } \\
\text { LKS/menyelesaia } \\
\text { kan tugas belajar }\end{array}$ & 15 & $\begin{array}{l}18.5 \\
7\end{array}$ & $\begin{array}{l}14 . \\
86\end{array}$ & $\begin{array}{l}16.1 \\
4\end{array}$ \\
\hline 6. & $\begin{array}{l}\text { Mempresentasika } \\
\mathrm{n} \text { hasil } \\
\text { percobaan/penga } \\
\text { matan }\end{array}$ & 10 & 10 & 10 & 10 \\
\hline 7. & $\begin{array}{l}\text { Mendengarkan } \\
\text { dan menyimak } \\
\text { presentasi }\end{array}$ & $\begin{array}{l}9.4 \\
3\end{array}$ & 9.43 & $\begin{array}{l}9.5 \\
7\end{array}$ & 9.48 \\
\hline 8. & $\begin{array}{l}\text { Memperlihatkan } \\
\text { perilaku tidak } \\
\text { relevan dengan } \\
\text { pembelajaran }\end{array}$ & $\begin{array}{l}2.1 \\
4\end{array}$ & 1.43 & $\begin{array}{l}1.8 \\
6\end{array}$ & 1.81 \\
\hline
\end{tabular}

Secara ringkas sktivitas siswa dapa disajikan dalam Gambar 3 berikut.

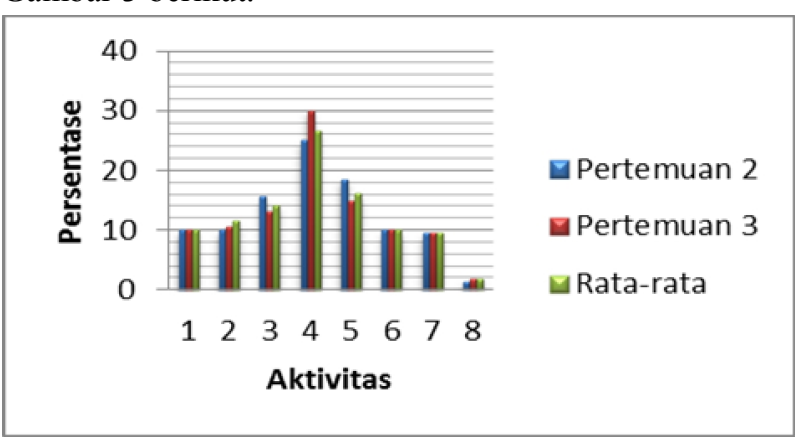

Gambar 3. Persentase aktivitas siswa 


\section{Hasil Belajar Siswa}

a. Hasil Belajar Aspek Pengetahuan Siswa

Nilai pre test digunakan untuk mengetahui aspek pengetahuan awal siswa. Nilai post test yang diperoleh siswa menggambarkan tentang hasil belajar pengetahuan siswa setelah mengikuti pembelajaran IPA terpadu tipe webbed berbasis inkuiri terbimbing. Pada saat pre test 4 dari 35 siswa tuntas secara individu, ketuntasan klasikal sebesar $11.43 \%$ yang artinya secara klasikal kelas belum dapat dikatakan tuntas karena ketuntasan klasikalnya kurang dari 75\% seperti yang ditetapkan oleh sekolah terkait. Setelah pembelajaran nilai yang diperoleh siswa mengalami peningkatan secara signfikan, ketuntasan klasikal mencapai 100\%. Hal ini menunjukkan bahwa penerapan hasil pengembangan perangkat dapat meningkatkan ketuntasan indikator pembelajaran aspek pengetahuan, didukung oleh perhitungan $\mathrm{N}$-gain rata-rata sebesar 0,76 dengan kriteria tinggi.

b. Kemandirian Belajar

Penilaian kemandirian belajar dinilai berdasarkan hasil pengamatan selama pembelajaran berlangsung. Hasil analisis ketercapaian aspek kemandirian belajar dapat dilihat pada Tabel 4 dan Diagram 4 berikut.

Tabel 4. Ketercapaian kompetensi Kemandirian belajar siswa

\begin{tabular}{|l|l|l|l|l|}
\hline No. & \multirow{2}{*}{$\begin{array}{l}\text { Kompetensi } \\
\text { Kemandirian }\end{array}$} & \multicolumn{3}{|l|}{ Ketuntasan (\%) } \\
\cline { 3 - 5 } & $\begin{array}{l}\text { Pertem } \\
\text { uan 1 }\end{array}$ & $\begin{array}{l}\text { Pertem } \\
\text { uan 2 }\end{array}$ & $\begin{array}{l}\text { Pertem } \\
\text { uan 3 }\end{array}$ \\
\hline 1. & Percaya diri & $70 \%$ & $84 \%$ & $85 \%$ \\
\hline 2. & $\begin{array}{l}\text { Mampu } \\
\text { mengendalikan } \\
\text { diri }\end{array}$ & $75 \%$ & $84 \%$ & $87 \%$ \\
\hline 3. & Tanggungjawab & $98 \%$ & $98 \%$ & $100 \%$ \\
\hline
\end{tabular}

Berdasarkan Tabel 4. ketercapaian aspek kemandirian belajar siswa dapat disajikan pada diagram 4 berikut:

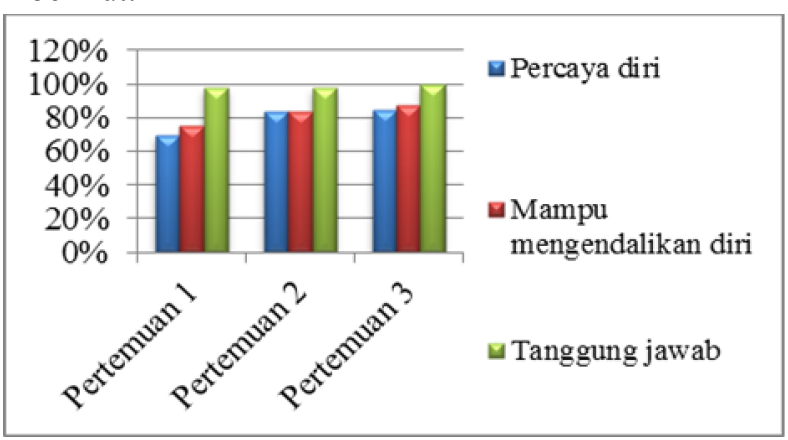

Gambar 4. Ketercapaian kompetensi Kemandirian belajar siswa

Berdasarkan analisis kemandirian belajar siswa yang disajikan pada Tabel 3.3 dan Gambar diagram 3.3 menunjukkan bahwa pada pertemuan 1, 2 dan 3 kompetensi kemandirian siswa memperoleh nilai $\geq$ 2,67, sehingga dapat disimpulkan bahwa pembelajaran dengan menerapkan perangkat pembelajaran IPA terpadu tipe webbed berbasis inkuiri terbimbing efektif untuk melatih kemandirian belajar siswa. Kemandirian belajar siswa yang diamati meliputi percaya diri, mampu mengendalikan diri dan tanggungjawab. Ratarata nilai siswa pada pertemuan 1 adalah 3.31, pertemuan 2 adalah 3.6 dan pertemuan 3 adalah 3.68 dan dinyatakan tuntas. Berdasarkan hasil pengamatan tersebut dapat dinyatakan bahwa kemandirian siswa meningkat pada setiap pertemuan.

c. Kecakapan Hidup

1) Kecakapan Akademik

Hasil analisis ketercapaian aspek kecakapan akademik dapat dilihat pada Tabel 5 berikut.

Tabel 5. Ketercapaian kompetensi Kecakapan Akademik

\begin{tabular}{|c|l|c|c|c|c|c|}
\hline No. & Kompetensi & \multicolumn{2}{|c|}{ Pre Test } & \multicolumn{2}{|c|}{ Post Test } & N-Gain \\
\cline { 2 - 7 } & & $\begin{array}{c}\text { Keterca } \\
\text { paian } \\
(\%)\end{array}$ & $\begin{array}{c}\text { Ketera } \\
\text { ngan }\end{array}$ & $\begin{array}{c}\text { Keterca } \\
\text { paian } \\
(\%)\end{array}$ & $\begin{array}{c}\text { Ketera } \\
\text { ngan }\end{array}$ & \\
\hline 1 & $\begin{array}{l}\text { Merumuskan } \\
\text { masalah }\end{array}$ & 26.19 & TT & 85 & T & 0.80 \\
\hline 2 & $\begin{array}{l}\text { Merumuskan } \\
\text { hipotesis }\end{array}$ & 33.81 & TT & 81 & T & 0.71 \\
\hline 3 & $\begin{array}{l}\text { Menentukan } \\
\text { variabel }\end{array}$ & 33.81 & TT & 83 & T & 0.74 \\
\hline 4 & $\begin{array}{l}\text { Membuat } \\
\text { rancangan } \\
\text { percobaan }\end{array}$ & 20 & TT & 76 & T & 0.70 \\
\hline 5 & $\begin{array}{l}\text { Menyajikan } \\
\text { hasil } \\
\text { pengamatan } \\
\text { dalam bentuk } \\
\text { Tabel }\end{array}$ & 43.81 & TT & 83.8 & T & 0.71 \\
\hline 6 & $\begin{array}{l}\text { Menganalisis } \\
\text { data }\end{array}$ & 37.14 & TT & 86 & T & 0.78 \\
\hline 7 & $\begin{array}{l}\text { Membuat } \\
\text { kesimpulan }\end{array}$ & 40 & TT & 86 & T & 0.77 \\
\hline & Rata-rata & 33.54 & TT & 82.97 & T & 0.74 \\
\hline
\end{tabular}

Keterangan: TT: Tidak Tuntas, $\quad$ T: Tuntas

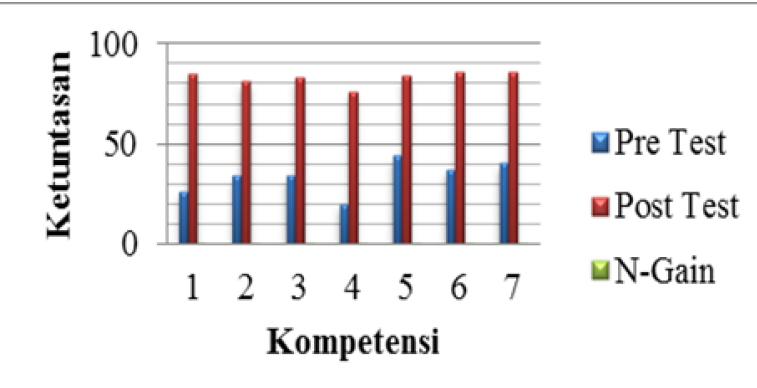

Gambar 5. Ketercapaian kompetensi Kecakapan Akademik

Berdasarkan Tabel 5 dan Gambar 5 diketahui setelah pembelajaran, kompetensi kecakapan akademik secara keseluruhan tercapai dan didapatkan n-gain ratarata 0.75 kategori tinggi (Hake, 1999). Peningkatan yang ditunjukkan oleh hasil analisis dengan 
menggunakan $N$-gain ini menunjukkan penerapan dari pengembangan perangkat pembelajaran IPA terpadu tipe webbed berbasis inkuiri terbimbing efektif dalam meningkatkan penguasaan kecakapan akademik siswa pada materi pencemaran air.

\section{2) Kecakapan Sosial}

Penilaian kemampuan social skills dinilai berdasarkan hasil pengamatan. Kemampuan social skills yang diamati adalah: a) kecakapan komunikasi yang meliputi; mengajukan pertanyaan, menjawab pertanyaan, mengemukakan pendapat, menanggapi pendapat, presentasi lisan, dan b) kecakapan bekerjasama. Kompetensi kecakapan sosial dapat disajikan pada Diagram 3.5 berikut.

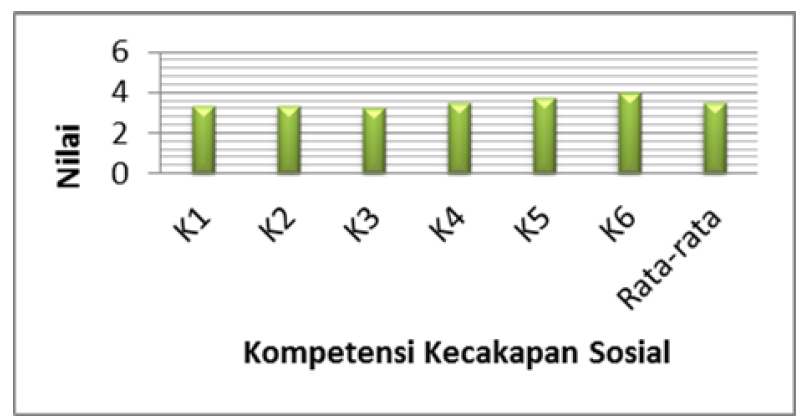

Gambar 6. Diagram Kecakapan Sosial

Keterangan:

$\mathrm{K} 1$ : mengajukan pertanyaan

$\mathrm{K} 2$ : menjawab pertanyaan

$\mathrm{K} 3$ : mengemukakan pendapat

K4 : menanggapi pendapat

$\mathrm{K} 5$ : presentasi lisan

K6:bekerjasama

Berdasarkan hasil analisis Gambar diagram 6 menunjukkan bahwa seluruh kompetensi kecakapan sosial siswa memperoleh nilai $\geq 2,67$, sehingga dpat disimpulkan bahwa pembelajaran dengan menerapkan perangkat pembelajaran IPA terpadu tipe webbed berbasis inkuiri terbimbing efektif untuk melatih kecakapan sosial siswa.

\section{Respon Siswa}

Berdasarkan hasil analisis respon siswa terhadap pengembangan perangkat pembelajaran (yang meliputi: buku siswa dan lembar kegiatan siswa), serta pelaksanaan pembelajaran dengan model inkuiri terbimbing secara rata-rata didapatkan hasil bahwa sebanyak $92.33 \%$ siswa merespon sangat positif dengan kriteria sangat kuat (Riduwan, 2010).

\section{KESIMPULAN}

\section{A. Simpulan}

Berdasarkan hasil penelitian yang meliputi analisis, diskusi, dan pembahasan, maka dapat dibuat simpulan bahwa perangkat pembelajaran IPA terpadu tipe webbed berbasis inkuiri terbimbing yang dikembangkan sudah valid, praktis, dan efektif untuk melatihkan kemandirian belajar dan kemampuan kecakapan hidup siswa SMP dalam pembelajaran IPA menggunakan model pembelajaran inkuiri terbimbing.

\section{B. Saran}

Berdasarkan pada hasil penelitian yang telah dilakukan, maka disampaikan saran-saran sebagai berikut:

1. Pembelajaran IPA terpadu tipe webbed berbasis inkuiri terbimbing memerlukan waktu lama sehingga disarankan pada penelitian lebih lanjut perlu memperhatikan persiapan dan waktu pelaksanaan pembelajaran, supaya proses pembelajaran dapat berlangsung dengan baik karena banyak waktu yang diperlukan untuk siswa berdiskusi dan mengerjakan kegiatan observasi.

2. Pengembangan perangkat pembelajaran perlu memperhatikan penggunaan bahasa dan tingkat kesulitan materi yang harus disesuaikan dengan tingkat kemampuan dan tingkat kelas siswa.

3. Peneliti lain perlu melatih siswa untuk lebih mengembangkan kemampuan yang diperlukan pada pembelajaran yang menggunakan kurikulum 2013, yaitu penggunaan keterampilan proses dan psikomotor dalam pembelajaran untuk melakukan kegiatan penyelidikan. Pengenalan awal bisa dilakukan pada waktu khusus, agar saat proses pembelajaran siswa tidak kesulitan menyelesaikan LKS dan melakukan penyelidikan.

4. LKS dan buku siswa yang digunakan pada saat pembelajaran lebih baik dibagikan kepada siswa sebelum pembelajaran dilaksanakan sehingga siswa lebih mudah dalam memahami LKS tersebut.

5. Secara keseluruhan pengembangan perangkat pembelajaran IPA terpadu tipe webbed berbasis inkuiri terbimbing dapat mengembangkan kemandirian belajar dan kecakapan hidup siswa SMP terutama pada academic skills dan social skills pada materi pencemaran sehingga diharapkan dilakukan penelitian lanjutan pada materi lain dan dengan pengembangan kecakapan hidup yang lainnya.

\section{REFERENSI}

Arikunto, Suharsimi. (2002). Dasar-dasar evaluasi pendidikan. Jakarta: Bumi Aksara.

Arikunto, suharsimi. (2010). "Prosedur penelitian". Jakarta: Rineka Cipta.

Branch, J. and Oberg, D. (2004). Focus on inquiry a teacher guide to implementing inquiry based learning. Canada: Alberta Education, Alberta.

Hake. (1999). Analyzing change/gain scores. Tersedia online:

http://www.physicsindiana.edu/sdi/Analyzing- 


\section{Cange-Gain.pdf.}

Harjasujana, A.S dan Yeti Mulyati. (1997). Membaca 2. Jakarta: Departemen Pendidikan dan Kebudayaan.

Kementerian Pendidikan dan Kebudayaan. (2013). Modul pelatihan implementaasi kurikulum 2013. Jakarta: Badan Pengembangan Sumber Daya Manusia Pendidikan dan Kebudayaan dan Penjaminan Mutu Pendidikan.

Kementerian Pendidikan dan Kebudayaan. (2013). Kurikulum 2013 Kompetensi Dasar Sekolah Menengah Pertama (SMP)/Madrasah Tsanawiyah (MTs). Jakarta: Kemendikbud.

Kementerian Pendidikan dan Kebudayaan. (2013). Permendikbud RI No. 65 Tahun 2013 tentang standar proses pendidikan dasar dan menengah. Jakarta: Kemendikbud.

Kementerian Pendidikan dan Kebudayaan. (2013). Permendikbud RI No. 66 Tahun 2013 tentang standar penilaian pendidikan. Jakarta: Kemendikbud.

Kementerian Pendidikan dan Kebudayaan. (2014). Permendikbud RI No. 104 Tahun 2014 tentang penilaian hasil belajar oleh pendidik pada pendidikan dasar dan pendidikan menengah. Jakarta: Kemendikbud.

Kuhlthau, C.C.and Todd. R.J.(2008). Guided inquiry. (Online). Tersedia. www. icwc.wikispaces.com/file/view/Guided+Inquiry. doc. Diakses 6 januari (2014).

Ratumanan, G.T. dan Laurens. (2006). Evaluasi hasil yang relevan dengan memecahkan problematika belajar dan mengajar. Bandung:CV Alfabeta.

Ratumanan, G.T. dan Laurens. (2011). Evaluasi hasil belajar pada tingkat satuan pendidikan. Surabaya: Unesa Unversity Press.

Riduwan. (2010). Skala Pengukuran Variabel-Variabel Penelitian. Bandung: Alfabeta.

Tuckman, B. W. (1875). Conducting educational research; second edition. USA: Harcout Brace Jovanovich, Publisher. 